\title{
Minireview on Regulation of Intestinal Calcium Absorption
}

\author{
Emphasis on Molecular Mechanisms of Transcellular Pathway
}

\author{
Adriana V. Pérez ${ }^{a} \quad$ Gabriela Picotto $^{a} \quad$ Agata R. Carpentieri $^{a}$ b María A. Rivoira $^{a}$ \\ María E. Peralta López ${ }^{a} \quad$ Nori G. Tolosa de Talamoni ${ }^{a}$ \\ aLaboratorio de Metabolismo Fosfocálcico 'Dr. Cañas', Cátedra de Bioquímica y Biología Molecular, Facultad de \\ Ciencias Médicas, y ${ }^{b}$ Cátedra de Química Biológica, Facultad de Odontología, Universidad Nacional de Córdoba, \\ Córdoba, Argentina
}

\section{Key Words \\ Intestinal absorption $\cdot \mathrm{Ca}^{2+} \cdot$ Transcellular pathway $\cdot$ Paracellular pathway $\cdot$ Vitamin D - Channels, TRPV5 and TRPV6 $\cdot \mathrm{Na}^{+} / \mathrm{Ca}^{2+}$ exchanger $\cdot$ Pregnancy $\cdot$ Growth}

\begin{abstract}
An overview of current information on the mechanisms by which intestinal calcium absorption occurs is described in this article. Both paracellular and transcellular pathways are analyzed. Special emphasis focuses on molecules participating in the latter pathway, such as TRPV 5 and TRPV 6 channels, located in the apical region of the enterocytes, $\mathrm{CB}_{9 \mathrm{k}}$ and $\mathrm{CB}_{28 \mathrm{k}}$, presumably involved in the cation movement from the apical to the basolateral pole of the cell, and $\mathrm{PMCA}_{1 \mathrm{~b}}$ and $\mathrm{Na}^{+} / \mathrm{Ca}^{2+}$ exchanger, proteins that extrude $\mathrm{Ca}^{2+}$ from the cells. Current concepts on the relative importance of paracellular and transcellular calcium transport and the vitamin $D$ dependence of each pathway are referred and analyzed showing the contrasting views on this issue. More detailed information is given regarding the stimulatory effect of vitamin D on intestinal $\mathrm{Ca}^{2+}$ absorption either in animal models or in the human intestine. The possible mechanisms triggered by hormones such as PTH, calcitonin, estrogen, thyroid hormone, glucocorticoids and different nutritional fac-
\end{abstract}

\section{KARGER}

Fax +41613061234

E-Mail karger@karger.ch

www.karger.com (c) 2008 S. Karger AG, Basel

$0012-2823 / 08 / 0771-0022 \$ 24.50 / 0$

Accessible online at:

www.karger.com/dig tors on intestinal calcium absorption are also reviewed. Finally, the influence of physiological conditions such as growth, pregnancy, lactation and aging on intestinal calcium absorption are discussed. Copyright $\odot 2008$ S. Karger AG, Basel

\section{Introduction}

Intestinal calcium $\left(\mathrm{Ca}^{2+}\right)$ absorption is an important process involved in the maintenance of $\mathrm{Ca}^{2+}$ homeostasis. It occurs by two main mechanisms: a transcellular, metabolically driven transport, and a passive non-saturable route, called the paracellular pathway [1]. These mechanisms are regulated by hormones, nutrients and other factors, which have been studied for many years due to their enormous relevance in the prevention of os-

N.G.T. de T., G.P. and A.R.C. are Career Investigators of the National Council of Scientific Investigation (CONICET, Argentina). M.E.P.L. is a fellow from the Secretary of Science and Technology, National University of Córdoba, SECYT (UNC), Argentina.

This work was supported by FONCYT (PICT 2005), CONICET (PIP 2005-6) and SECYT (UNC). 
teoporosis and other abnormalities related to the $\mathrm{Ca}^{2+}$ metabolism. The transcellular pathway is mainly regulated by vitamin $\mathrm{D}$, precisely by its hormonal metabolite $1,25(\mathrm{OH})_{2} \mathrm{D}_{3}$, via transcriptional activation of genes through binding of the ligand to the classical nuclear vitamin D receptor (VDR) [2]. Some polymorphisms of VDR such as the Fok I polymorphic site seem also to affect intestinal $\mathrm{Ca}^{2+}$ absorption [3] by a not well-understood mechanism.

Under physiological conditions, $\mathrm{Ca}^{2+}$ ions are absorbed mainly in the small intestine, responsible for about $90 \%$ of overall $\mathrm{Ca}^{2+}$ absorption [4]. In rat small intestine, Marcus and Lengemann [5] found that $88 \%$ of $\mathrm{Ca}^{2+} \mathrm{ab}-$ sorption occurs in the ileum, $4 \%$ in the jejunum, and $8 \%$ in the duodenum. In dogs, Cramer [6] found 80, 16 and $4 \%$ in ileum, jejunum and duodenum, respectively. The longer residence time of $\mathrm{Ca}^{2+}$ in the ileum as compared to the other intestinal segments favors $\mathrm{Ca}^{2+}$ absorption in that segment. The transit half-time in rat ileum is around $100-120 \mathrm{~min}$, whereas in the duodenum it is around 2-6 min $[5,6]$. Minor amounts of $\mathrm{Ca}^{2+}$ ions are absorbed from the stomach and large intestine; the colon accounts for less than $10 \%$ of the total $\mathrm{Ca}^{2+}$ absorbed [4]. The major contributors to the amount of $\mathrm{Ca}^{2+}$ absorbed are the residence time and the rate of absorption in the particular segment. The order of absorption rate is: duodenum $>$ jejunum $>$ ileum [7]. Colonic $\mathrm{Ca}^{2+}$ absorption is also vitamin D-responsive and it is quite possible that it becomes important in conditions such as short bowel syndrome [8].

The bioavailability of dietary $\mathrm{Ca}^{2+}$ affects the efficiency of intestinal $\mathrm{Ca}^{2+}$ absorption. Low $\mathrm{Ca}^{2+}$ diets increase the intestinal $\mathrm{Ca}^{2+}$ absorption ratio, at least in part, by altering the vitamin $\mathrm{D}$ endocrine system $[9,10]$ and the lipid composition and fluidity of intestinal membranes [11].

Variability of intestinal $\mathrm{Ca}^{2+}$ absorption is also related to the physiological $\mathrm{Ca}^{2+}$ needs, but in general when the requirements increase and/or the intake is low, the efficiency of $\mathrm{Ca}^{2+}$ absorption improves [11]. Growth, pregnancy and lactation stimulate intestinal $\mathrm{Ca}^{2+}$ absorption, whereas aging is accompanied by a decrease in the absorption of the cation.

\section{Paracellular Pathway}

The intestinal epithelium is a continuous layer of individual cells with very narrow spaces between them that allow the diffusion of small molecules and ions [12]. The paracellular pathway must be regulated by the epithelium in order to maintain the selective permeability. Tight junctions constitute a barrier to the movement of molecules and ions through this pathway. These junctions are specialized membrane domains located in the apical region of enterocytes. They are intercellular structures where the plasma membranes of adjacent cells come into very close contact [12]. The proteins that form these structures are synthesized in the adjacent cells and they include occludin and another protein member of the claudin family [13]. Movement of $\mathrm{Ca}^{2+}$ through the tight junctions is a passive process that depends on the concentration and the electric gradients across the epithelium. It is a passive non-saturable process that prevails in the jejunum and ileum, mainly when $\mathrm{Ca}^{2+}$ intake is adequate or high [14]. It depends on the solubility of $\mathrm{Ca}^{2+}$ in the distal small intestine, the length of sojourn of the chyme in a particular intestinal segment and the rate of diffusion from the lumen to lymph or blood [14]. When $\mathrm{Ca}^{2+}$ intake is high, the paracellular pathway becomes important because the sojourn time in the intestine is short and the proteins involved in the transcellular route are downregulated [15].

\section{Transcellular Pathway}

\section{Epithelial $\mathrm{Ca}^{2+}$ Channels}

The molecules involved in the apical $\mathrm{Ca}^{2+}$ entry step in the intestine remained unknown until the discovery of the epithelial $\mathrm{Ca}^{2+}$ channels TRPV5 (previously named ECaC1 or CaT2) and TRPV6 (previously named ECaC2 or CaT1) [16]. Both channels are homologous members of the transient receptor potential (TRP) superfamily, belonging precisely to the vanilloid subfamily (TRPV) to be differentiated from the canonical (TRPC) and melastatin subfamilies (TRPM). The pattern of expression of these proteins is quite variable, which can be due to differences between species or expressions below detection levels [17]. TRPV5 is the major isoform in the kidney, while TRPV6 is highly expressed in the intestine. However, TRPV5 and TRPV6 are coexpressed in human kidney and intestine, and also in other organs such as pancreas, prostate, mammary, sweat and salivary glands [16]. TRPV5 and TRPV6 have 75\% homology and their main differences are located in the $\mathrm{N}$ and $\mathrm{C}$ terminal tails. Both channels permeate $\mathrm{Ca}^{2+}$ ions, but they also permeate other divalent cations and monovalent cations in the absence of divalent ones. These channels have three unique properties: (1) they have a constitutively activated $\mathrm{Ca}^{2+}$ perme- 
ability; (2) the selectivity for $\mathrm{Ca}^{2+}$ over $\mathrm{Na}^{+}$is much larger than in other members of the TRP family $\left(\mathrm{P}_{\mathrm{Ca}} / \mathrm{P}_{\mathrm{Na}}\right.$ $>100$ ), and (3) the current-voltage relationship of both channels shows inward rectification instead of outward rectification as shown by other TRPV channels. The structure of these channels is similar to that of other members of the TRP family, including 6 transmembrane domains, a short hydrophobic stretch between segments 5 and 6 which would be involved in the $\mathrm{Ca}^{2+}$ pore and large intracellular $\mathrm{N}$ and $\mathrm{C}$ terminal tails [17]. The intracellular segments contain regulatory sites involved in the regulation of channel activity and trafficking. Among them, there are phosphorylation sites, postsynaptic density protein (zona occludens) motifs, and ankyrin repeat domains. All of them participate in the maintenance of the activity of the channels, in the interaction with other proteins, and in the targeting of those channels to specific membrane regions [17].

Hoenderop et al. [18] demonstrated that channels TRPV 5 and TRPV6 have a tetrameric structure and they can combine each other to form heterotetrameric channel complexes with novel properties. The tetrameric architecture of TRPV5/6 implies that 4 aspartic residues form a ring that is negatively charged and functions as a selective filter for $\mathrm{Ca}^{2+}$.

Although both channels originate from two genes juxtaposed on human chromosome $7 \mathrm{q} 35$, the proteins share several properties and have some differences. At the transcriptional level, they are regulated by $1,25(\mathrm{OH})_{2} \mathrm{D}_{3}$, estrogen and dietary $\mathrm{Ca}^{2+}$. Regarding the activity, both are inactivated by intracellular $\mathrm{Ca}^{2+}$, but the inactivation of TRPV6 shows two phases, whereas that of TRPV5 shows only a slow inactivation phase. The affinity of TRPV 5 for the inhibitor ruthenium red is 100 times higher than that of TRPV6 [19].

TRPV5 and TRPV6 are located in the brush border membrane of enterocytes and it is quite possible that they are the rate-limiting entry step of active intestinal $\mathrm{Ca}^{2+}$ absorption [20]. To determine the in vivo function of TRPV6, Bianco et al. [21] generated mice with targeted disruption of the TRPV6 gene. They have demonstrated that TRPV6 knockout (KO) mice were viable but showed a $60 \%$ decrease in intestinal $\mathrm{Ca}^{2+}$ absorption, deficient weight gain, decreased bone mineral density (BMD), and lower fertility. Their data indicate that the TRPV6 channel not only plays a role in the tissues directly involved in $\mathrm{Ca}^{2+}$ homeostasis, but also in other tissues.

Walters et al. [22] characterized TRPV6 transcript expression in normal human intestinal biopsies. TRPV6 transcripts were detected in the duodenum but not in the ileum. Duodenal expression of TRPV6 was vitamin Ddependent in men; however, in elderly women TRPV6 and VDR expressions were reduced and were not vitamin D-dependent, which can explain, at least in part, the lower intestinal $\mathrm{Ca}^{2+}$ absorption in elderly postmenopausal women.

\section{Calbindins}

There are two calbindins (CBs) thought to be responsible for removing $\mathrm{Ca}^{2+}$ from the apical side of the enterocytes and carrying the $\mathrm{Ca}^{2+}$ transcellular movement to the basal region of the cell. In the duodenum, CB $\mathrm{D}_{28 \mathrm{k}}$ $\left(\mathrm{CB}_{28 \mathrm{k}}\right)$ is present in the avian species, while $\mathrm{CB} \mathrm{D}_{9 \mathrm{k}}$ $\left(\mathrm{CB}_{9 \mathrm{k}}\right)$ is present in mammals [23]. Both proteins are encoded by separate genes. It has been proposed that CBs not only carry $\mathrm{Ca}^{2+}$ ions from the entry side to the basolateral membrane (BLM) of the enterocyte, but also buffer $\mathrm{Ca}^{2+}$ ions providing protection against toxic $\mathrm{Ca}^{2+}$ levels during high $\mathrm{Ca}^{2+}$ influx. In addition, $\mathrm{CBs}$ may function as $\mathrm{Ca}^{2+}$ sensors due to their biochemical properties related to their EF-hand motifs. $\mathrm{CB}_{28 \mathrm{k}}$ has 6 EF-hand motifs that bind $\mathrm{Ca}^{2+}$ in a cooperative fashion. Nuclear magnetic resonance analyses indicated that $\mathrm{Ca}^{2+}$ binding to $\mathrm{CB}_{28 \mathrm{k}}$ produce conformational changes in the protein [24]. Lambers et al. [25] have shown that renal $\mathrm{CB}_{28 \mathrm{k}}$ acts as a dynamic $\mathrm{Ca}^{2+}$ buffer, regulating the $\mathrm{Ca}^{2+}$ concentration in the vicinity to the TRPV5 pore by a direct association with the channel. Similar mechanisms could occur in the intestine and other tissues where CBs are abundant and where cells tolerate important fluctuations in intracellular $\mathrm{Ca}^{2+}$ concentration.

Genetic studies give controversial data regarding the role of $\mathrm{CBs}$ on $\mathrm{Ca}^{2+}$ homeostasis. Ablation of $\mathrm{CB}_{28 \mathrm{k}}$ gene in mice does not produce calcemic abnormalities [26]. VDR KO mice show hypocalcemia, secondary hyperparathyroidism, rickets and a $90 \%$ reduction in renal $\mathrm{CB}_{9 \mathrm{k}}$ expression with no change in $\mathrm{CB}_{28 \mathrm{k}}$. $\mathrm{VDR} / \mathrm{CB}_{28 \mathrm{k}}$ double $\mathrm{KO}$ mice develop more severe secondary hyperparathyroidism and rachitic skeletal phenotype, and the rescue diet with high calcium and lactose does not completely correct the skeletal alterations. The authors think that $\mathrm{CB}_{28 \mathrm{k}}$ plays an important role in $\mathrm{Ca}^{2+}$ homeostasis and suggest that its calcemic role might be compensated by $\mathrm{CB}_{9 \mathrm{k}}$ [27]. However, recent data from $\mathrm{CB}_{9 \mathrm{k}} \mathrm{KO}$ mice indicate that those mice are not different from wild-type mice in phenotype and $\mathrm{Ca}^{2+}$ serum level [28]. In addition, the $\mathrm{CB}_{9 \mathrm{k}}$ null mutant mice are able to absorb $\mathrm{Ca}^{2+}$ from the intestine in response to $1,25(\mathrm{OH})_{2} \mathrm{D}_{3}$, which would mean that $\mathrm{CB}_{9 \mathrm{k}}$ is not required for vitamin $\mathrm{D}$-dependent intestinal $\mathrm{Ca}^{2+}$ absorption. 


\section{$\mathrm{Ca}^{2+}$ Pump and $\mathrm{Na}^{+} / \mathrm{Ca}^{2+}$ Exchanger}

The exit of $\mathrm{Ca}^{2+}$ ions from enterocytes to the lamina propria is performed by two molecules: the plasma membrane Ca-ATPase or $\mathrm{Ca}^{2+}$ pump (PMCA) and the $\mathrm{Na}^{+}$/ $\mathrm{Ca}^{2+}$ exchanger (NCX1). The $\mathrm{Ca}^{2+}$ pump has a $\mathrm{M}_{\mathrm{r}}$ of 130 $\mathrm{kDa}$ and $\mathrm{K}_{\mathrm{m}}$ for $\mathrm{Ca}^{2+}$ of $0.2 \mu \mathrm{M}$ in the presence of calmodulin [29]. It is located in small invaginations in the plasma membrane, called caveolae, which can exist in open and closed forms that control $\mathrm{Ca}^{2+}$ efflux from the cell [30]. It presents several isoforms but, apparently, $\mathrm{PMCA}_{1 \mathrm{~b}}$ is the predominant form in the intestine. The expression and activity of $\mathrm{PMCA}_{1 \mathrm{~b}}$ is higher in enterocytes from the villus tip as compared to those from the villus crypt, which supports the idea that mature enterocytes have the greatest capacity for transcellular $\mathrm{Ca}^{2+}$ movement [10]. Vitamin D deficiency decreases the expression and activity of $\mathrm{PMCA}_{1 \mathrm{~b}}$ in chick intestine, which is partially reversed by a single large dose of cholecalciferol [31].

The intestinal $\mathrm{Na}^{+} / \mathrm{Ca}^{2+}$ exchanger, which has received little attention, is responsible for about $20 \%$ of $\mathrm{Ca}^{2+}$ extrusion and its activity depends on the gradient created by $\mathrm{Na}^{+} / \mathrm{K}^{+}$-ATPase [32]. There are several isoforms that result from three different genes [33]. The $\mathrm{Na}^{+} / \mathrm{Ca}^{+}$exchanger is present in the intestine. It has a $\mathrm{M}_{\mathrm{r}}$ of $90 \mathrm{kDa}$ and it is constituted by 11 transmembrane domains and an intracellular loop between segments 5 and 6 . In this loop there is an inhibitory region involved in the inactivation of the exchanger, named exchange inhibitory peptide domain and a regulatory site with high affinity for $\mathrm{Ca}^{2+}$. The stoichiometry of exchange of this protein is $3 \mathrm{Na}^{+}: 1 \mathrm{Ca}^{2+}$ [34]. In the intestine, the $\mathrm{Na}^{+} / \mathrm{Ca}^{2+}$ exchanger has been detected in rats [32], mice [35] and chicks [10], but not in rabbits [36]. This transporter can operate in either a forward mode $\left(\mathrm{Ca}^{2+}\right.$ exit) or in a reversed mode $\left(\mathrm{Ca}^{2+}\right.$ entry), which depends on the $\mathrm{Na}^{+}$and $\mathrm{Ca}^{2+}$ gradients and the potential across the plasma membrane [37]. The expression and activity of the $\mathrm{Na}^{+} / \mathrm{Ca}^{2+}$ exchanger is quite similar between mature and immature enterocytes, being slightly higher in the villus tip cells [10].

\section{Regulation by Calcitriol or $1,25(\mathrm{OH})_{2} \mathrm{D}_{3}$}

Calcitriol or $1,25(\mathrm{OH})_{2} \mathrm{D}_{3}$ induces changes in the structure and function of intestinal epithelial cells, which results in an increased intestinal $\mathrm{Ca}^{2+}$ absorption. As previously mentioned, calcitriol primarily stimulates the transcellular $\mathrm{Ca}^{2+}$ movement. Calcitriol enhances intestinal $\mathrm{Ca}^{2+}$ absorption through binding to VDR, nuclear receptor and transcription factor. This binding promotes heterodimerization with the retinoid $\mathrm{X}$ receptor (RXR). The $1,25(\mathrm{OH})_{2} \mathrm{D}_{3}$-VDR-RXR complex translocates to the nucleus to bind the vitamin D-responsive element(s) (VDRE) that is (are) usually located on the DNA upstream of the transcription site. Thus, the VDR complex can regulate gene transcription [38]. The four proteins or their transcripts considered to be essential for transcellular $\mathrm{Ca}^{2+}$ absorption (TRPV6, CB, calcium pump and $\mathrm{Na}^{+} / \mathrm{Ca}^{2+}$ exchanger) are known to be enhanced by calcitriol in mouse and chick intestine [10,31, 39-41]. However, recent data obtained in $\mathrm{CB}_{9 \mathrm{k}}$ null mutant mice indicate that $\mathrm{CB}_{9 \mathrm{k}}$ is not required by calcitriol-mediated $\mathrm{Ca}^{2+}$ absorption in the small intestine [42].

The sensitivity of the genes related to the intestinal $\mathrm{Ca}^{2+}$ absorption to the VDR levels remains unclear. VDR $\mathrm{KO}$ mice have a phenotype of vitamin D-resistance rickets and reduced calcium absorption [43]. Song and Fleet [2] tested the role of VDR levels in the intestinal response to calcitriol in wild-type mice and mice lacking one VDR allele (heterozygous) that have only half the intestinal VDR content. They found that a reduced intestinal VDR level causes vitamin $\mathrm{D}$ resistance and impairs intestinal $\mathrm{Ca}^{2+}$ absorption in mice. The resistance is not uniform in the vitamin $\mathrm{D}$-dependent genes involved in the intestinal $\mathrm{Ca}^{2+}$ absorption, because apparently the effects of VDR levels have been only detected in the translation of $\mathrm{CB}_{9 \mathrm{k}}$. Meyer et al. [44], by using a chromatin immunoprecipitation scanning method, have identified multiple VDREs in the distal promoter region of the TRPV6 gene. It is quite possible that the number of VDREs in each promoter, the location or the local DNA environment of each VDRE or the affinity of each VDRE for VDR could account for the differential sensitivity of each gene involved in the intestinal $\mathrm{Ca}^{2+}$ absorption to VDR level [2]. In addition, differences in the promoters of the genes for intestinal $\mathrm{Ca}^{2+}$ absorption proteins or for VDR could also explain the interspecies differences in responsiveness to calcitriol between humans and experimental animals [45].

The well-known rapid effects (minutes to an hour) of calcitriol on $\mathrm{Ca}^{2+}$ uptake by epithelial cells or other responses brought up the question about the possibility of a second VDR located in the plasma membrane. It now appears that the classic VDR could also be associated with caveolae present in the plasma membrane [46].

Regarding the vitamin D dependency of the paracellular pathway, the picture is less clear as compared to the transcellular pathway. However, some data indicate that vitamin $\mathrm{D}$ increases tight-junction conductance and paracellular $\mathrm{Ca}^{2+}$ transport in Caco-2 cell lines [47]. It 
Fig. 1. Schematic representation of possible mechanisms involved in the intestinal $\mathrm{Ca}^{2+}$ absorption. The epithelial $\mathrm{Ca}^{2+}$ transport occurs by paracellular and transcellular pathways. The paracellular $\mathrm{Ca}^{2+}$ transport is carried out through tight junctions (TJ) by an electrochemical gradient (long arrow between cells). The transcellular $\mathrm{Ca}^{2+}$ transport consists of three steps: (1) apical entry of $\mathrm{Ca}^{2+}$ through epithelial $\mathrm{Ca}^{2+}$ channels TRPV5 and TRPV6 (the last one is the most abundant in intestine); (2) cytosolic diffusion bound to calbindins, and (3) extrusion across the basolateral membranes by the plasma membrane $\mathrm{Ca}^{2+}$-ATPase $\left(\mathrm{PMCA}_{1 \mathrm{~b}}\right)$ and the $\mathrm{Na}^{+} / \mathrm{Ca}^{2+}$ exchanger (NCX1). Calcitriol $\left(1,25(\mathrm{OH})_{2} \mathrm{D}_{3}\right)$ stimulates the individual steps of transcellular $\mathrm{Ca}^{2+}$ transport. Calcitriol molecules bind to their nuclear receptors (VDR), and the complex $1,25(\mathrm{OH})_{2} \mathrm{D}_{3}$-VDR interacts with specific DNA sequences inducing transcription and increasing the expression levels of TRPV 5/6, calbindins and the extrusion systems.

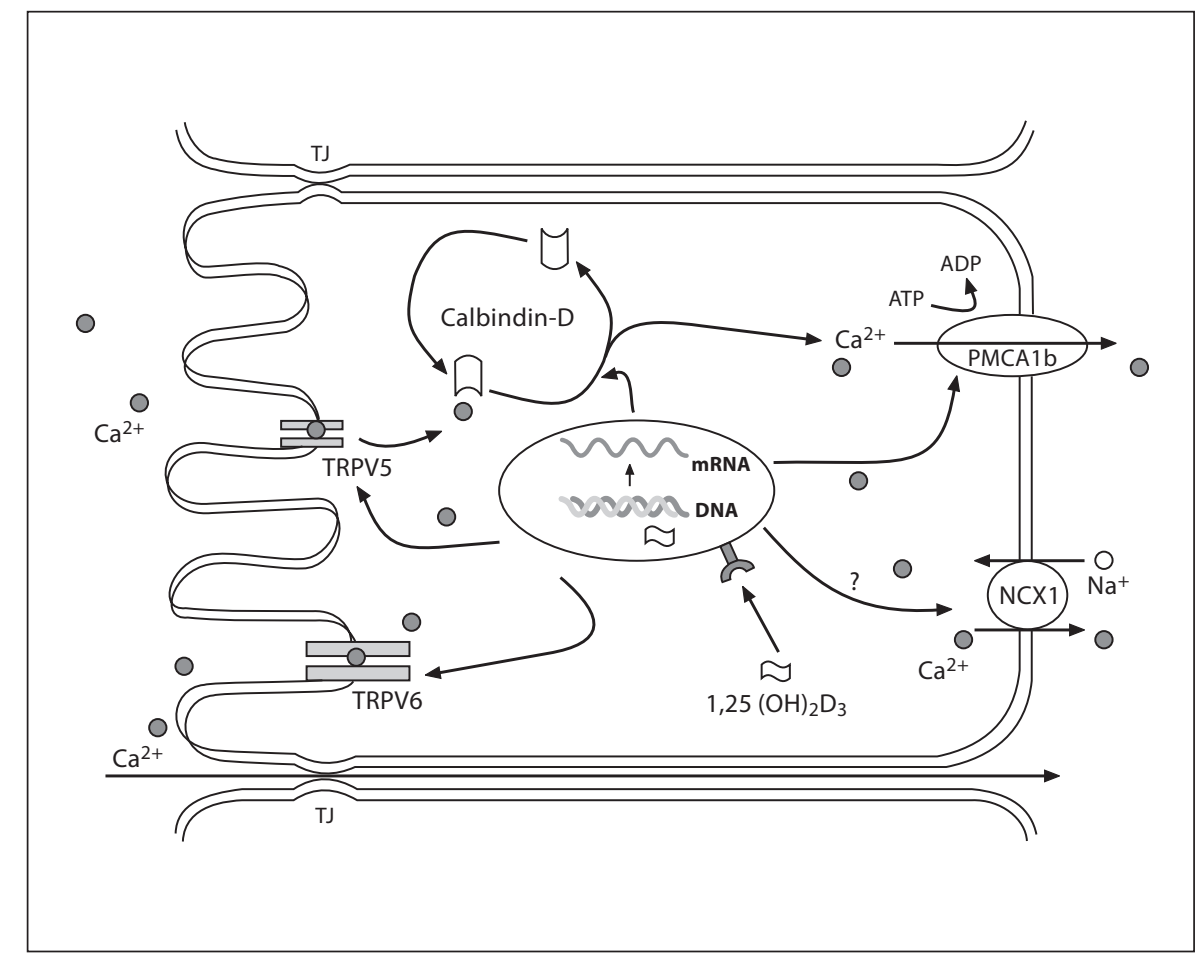

has been reported that $1,25(\mathrm{OH})_{2} \mathrm{D}_{3}$ activates protein $\mathrm{ki}$ nase $\mathrm{C}$, which apparently increases paracellular permeability by affecting cytoskeleton activity [48].

Figure 1 is a schematic representation of the possible mechanisms involved in the intestinal $\mathrm{Ca}^{2+}$ absorption triggered by calcitriol as has been described above.

\section{Relative Importance of Paracellular and Transcellular Calcium Transport and the Vitamin D-Dependence of Each Pathway}

It is still debated whether intestinal $\mathrm{Ca}^{2+}$ absorption takes place predominantly through a passive or an active process and whether vitamin $\mathrm{D}$ constitutes a major regulator of the passive paracellular pathway. Interesting analyses and opinions regarding this issue have been reported by McCormick [49], Bronner et al. [50] and Wasserman [4]. Basically, McCormick [49] refers to evidence indicating that the contribution of passive diffusion is about $8-23 \%$ in normal adults, while in children this process is of little practical significance. The author cited two different studies on children lacking a VDR system [51, 52] that did not show improvement in their calcium status by oral calcium supplementation, but instead presented beneficial effects of calcium infusion as early as 2 weeks later. Besides, through analysis of data from Bronner et al. [53] and Pansu et al. [54], he suggested that, early in development and for several weeks after birth, intestinal $\mathrm{Ca}^{2+}$ absorption depends on passive diffusion and not on vitamin $\mathrm{D}$-dependent processes. This would change with the age, becoming more important the saturable process that requires vitamin $\mathrm{D}$ in the adulthood. In addition, McCormick suggested that species differences could also complicate the interpretation of the relative importance of both pathways.

On the contrary, Bronner et al. [50] reported that the estimation of passive transport from the data of Ireland and Fordtran [55] must be calculated using a value of diffusible plasma calcium of 1.1-1.2 mmol/l instead of 1.5 $\mathrm{mmol} / \mathrm{l}$. This would almost double the slope of passive diffusion, and with the new approach that they suggested, the active transport accounted for only $27 \%$. Bronner et al. [50] also cite the data of Sheikh et al. [56], who reported that when healthy young subjects increased their $\mathrm{Ca}^{2+}$ intake from 502 to $1,071 \mathrm{mg} /$ day, their total absorption doubled, the increase being due to the vitamin D-independent passive transport. Although Bronner et al. [50] point out that vitamin $\mathrm{D}$ administration increases intestinal $\mathrm{Ca}^{2+}$ absorption, they consider that increasing $\mathrm{Ca}^{2+}$ intake is more effective and involves less risk for normal adults. 
Contrary to the aforementioned views, Wasserman [4] presented evidence that both paracellular and transcellular pathways are positively affected by vitamin $D$ in the ileum, the site where most of the dietary $\mathrm{Ca}^{2+}$ is absorbed. The author mentions several papers $[57,58]$ demonstrating that the ileum can absorb $\mathrm{Ca}^{2+}$ by an active process which is stimulated by vitamin $\mathrm{D}$. Wasserman [4] suggests that the slower rate of absorption in the ileum as compared to the duodenum might be the absence of an entry $\mathrm{Ca}^{2+}$ channel in the rat ileum (but present in the human and mouse ileum) and the lower $\mathrm{CB}$ and $\mathrm{Ca}^{2+}$ pump concentrations compared with the duodenum, but the long transit time of the cation in the ileum would have a considerable effect on overall $\mathrm{Ca}^{2+}$ absorption. Wasserman [4] also suggests that calcitriol might control the paracellular permeability as was previously demonstrated in other systems by different hormones.

\section{Regulation by Other Hormones}

\section{Parathyroid Hormone}

It is well known that parathyroid hormone (PTH) plays an important role in the maintenance of the extracellular $\mathrm{Ca}^{2+}$ concentration, sensing minute by minute changes in the blood $\mathrm{Ca}^{2+}$. When the extracellular $\mathrm{Ca}^{2+}$ is low, the parathyroid glands secrete PTH to the circulation and then PTH binds to the $\mathrm{PTH} / \mathrm{PTH}$ receptor protein (PTHrP) receptor, mainly in the bone and kidney stimulating bone resorption and $\mathrm{Ca}^{2+}$ reabsorption, respectively. At the intestinal level, PTH seems to act indirectly on intestinal $\mathrm{Ca}^{2+}$ absorption by stimulation of renal $1 \alpha$-hydroxylase and, thereby, increasing $1,25(\mathrm{OH})_{2} \mathrm{D}_{3}$-dependent absorption of $\mathrm{Ca}^{2+}$ from the intestine. However, direct effects of PTH on $\mathrm{Ca}^{2+}$ uptake by enterocytes from rat duodenum have been demonstrated. PTH stimulates enterocyte $\mathrm{Ca}^{2+}$ influx, which could be blocked by the $\mathrm{Ca}^{2+}$ channel antagonists verapamil and nitrendipine [59], and modulates intracellular $\mathrm{Ca}^{2+}$ concentration [60]. Furthermore, PTH/PTHrP receptors have been localized by immunocytochemistry in intestinal epithelial cells along the villus [61]. Aside from its rapid signal transduction mechanism, PTH also promotes nuclear effects such as regulation of gene transcription and cell proliferation $[61,62]$. Studies that demonstrated the direct effect of PTH on the global process of intestinal $\mathrm{Ca}^{2+}$ absorption have not been reported yet.

Intestinal $\mathrm{Ca}^{2+}$ Absorption

\section{Calcitonin}

Although calcitonin is considered one of the three major regulating hormones of plasma calcium, little information is available about its effect on intestinal calcium absorption. Jaeger et al. [63] have studied the effect of chronic calcitonin infusion in thyroparathyroidectomized animals. Calcitonin increased plasma calcium levels in animals on a regular diet by $50 \%$, which was most likely due to an enhancement of intestinal calcium absorption since removal of calcium from the diet markedly blunted this effect. The authors concluded that calcitonin stimulates intestinal calcium absorption through an increase in $1,25(\mathrm{OH})_{2} \mathrm{D}_{3}$ circulating levels. Afterwards, Yoshida et al. [64] demonstrated that calcitonin stimulates the 25-hydroxyvitamin $\mathrm{D}_{3} \quad 1 \alpha$-hydroxylase mRNA level in LLC-PK 1 cells via the protein kinase C pathway. So far, there have been no reports of pathologies caused by either calcitonin deficiency or excess [65].

\section{Thyroid Hormone}

Thyrotoxicosis is quite often accompanied by hypercalcemia in either humans or animals $[66,67]$. However, this issue has received little attention. Cross et al. [68, 69] reported that thyroid hormone and vitamin $\mathrm{D}$ have a cooperative effect not only on intestinal calcium transport but also on intestinal phosphate movement. The authors also demonstrated that thyroid hormones increase the genomic action of calcitriol in the intestine. Recently, it has been shown that hyperthyroid rats show higher $\mathrm{Ca}^{2+}$ uptake by brush border membrane vesicles and $\mathrm{Ca}^{2+}$ efflux from the BLMs of enterocytes than hypothyroid rats. $\mathrm{Ca}^{2+}$-ATPase activity was not changed by the thyroid hormones, while the $\mathrm{Na}^{+} / \mathrm{Ca}^{2+}$ exchanger activity was highly increased possibly via the cAMP-mediated pathway [67].

\section{Estrogen}

Several studies have reported that the global $\mathrm{Ca}^{2+} \mathrm{ab}-$ sorption in normal postmenopausal women is decreased, an effect that is more pronounced in postmenopausal osteoporotic women [70]. Estrogen therapy corrects the decline in $\mathrm{Ca}^{2+}$ absorption efficiency at the onset of menopause as indicated by cell culture studies [71]. However, the mechanisms that underlie this effect are not clear. Some studies indicate that estrogen acts independently of $1,25(\mathrm{OH})_{2} \mathrm{D}_{3}$ in the intestine [72], whereas others suggest that estrogen modifies intestinal $\mathrm{Ca}^{2+}$ absorption through the vitamin D endocrine system [71]. Most of the estrogen studies were performed in ovariectomized animals. This ablation significantly reduces endogenous estrogen

Digestion 2008;77:22-34 
production, but not completely due to the fact that adrenal androgens can be aromatized to estrogen [70]. Because of that, $\mathrm{KO}$ animals for estrogen receptor- $\alpha(\mathrm{ER} \alpha)$ and ER $\beta$ were obtained to totally abolish the genomic actions of estrogen mediated by their receptors. $\mathrm{ER} \alpha \mathrm{KO}$ mice showed a decrease in the duodenal ECaC2 mRNA expression, while $\mathrm{CB}_{9 \mathrm{k}}, \mathrm{PMCA}_{1 \mathrm{~b}}$ and VDR levels were unchanged. ER $\beta K O$ mice did not change the genes for intestinal calcium transporter. Apparently, in mice the genomic effects of estrogen are mainly mediated by the $\mathrm{ER} \alpha$. This concept must not be extrapolated to humans because it has been demonstrated that in normal colon and cancer colon cells the subtype $\beta$ is the predominant form of the ER [73].

Van Abel et al. [74] supplemented ovariectomized rats with estradiol and found increased duodenal gene expression of TRPV5, TRPV6, CB ${ }_{9 \mathrm{k}}$ and PMCA $\mathrm{P}_{1 \mathrm{~b}}$. In addition, they used 25-hydroxyvitamin $\mathrm{D}_{3} 1 \alpha$-hydroxylase $\mathrm{KO}$ mice to study the $1,25(\mathrm{OH})_{2} \mathrm{D}_{3}$ dependency of the stimulatory effects of estradiol on intestinal $\mathrm{Ca}^{2+}$ absorption. Under this condition of undetectable levels of $1,25(\mathrm{OH})_{2} \mathrm{D}_{3}$, the estradiol treatment increased mRNA levels of duodenal TRPV6. During pregnancy or lactation, estrogen or hormonal changes produce vitamin $\mathrm{D}$ independent effects at the genomic level on duodenal calcium absorption. Estrogen seems to upregulate the calcium influx channel CaT1, which apparently is only mediated by ER $\alpha$ [75]. Cotter and Cashman [76] have investigated the effect of two dietary phytoestrogens (coumestrol and apigenin) as well as ipriflavone, a synthetic phytoestrogen, on $\mathrm{Ca}$ absorption in the human Caco- 2 cell line. The authors did not find a direct effect of these compounds on intestinal $\mathrm{Ca}$ absorption. These equivocal results evidence that further studies are needed to clarify the mechanism(s) triggered by estrogen in intestine.

\section{Glucocorticoids}

Glucocorticoids (GCs) are extensively used as anti-inflammatory drugs. Osteoporosis is one of the most important side effects after long-term GC treatments. Reduced intestinal $\mathrm{Ca}^{2+}$ absorption seems to be part of the pathogenesis of GC-induced osteoporosis [77]. However, the mechanisms triggered by GCs on the intestine are not clear. Some data have shown that short-term GC excess in young animals affects bone metabolism but not the expression of genes involved in intestinal $\mathrm{Ca}^{2+}$ absorption such as TRPV6, $\mathrm{CB}_{9 \mathrm{k}}$ and $\mathrm{PMCA}_{1 \mathrm{~b}}$ [78]. In contrast, sustained dexamethasone suppresses mouse duodenal $\mathrm{CB}_{9 \mathrm{k}}$ expression via the GC receptor pathway [79]. Re- cently, it has been reported that $10 \mathrm{mg} / \mathrm{kg}$ body weight prednisolone for 10 days decreases rat intestinal $\mathrm{Ca}^{2+} \mathrm{ab}-$ sorption through diminished expression of the active calcium transporters such as the channel TRPV6 and $\mathrm{CB}_{9 \mathrm{k}}$, independently of $1,25(\mathrm{OH})_{2} \mathrm{D}_{3}$ [80]. A similar finding was also reported by Scholz-Ahrens et al. [81]. These authors used adult Göttingen miniature pigs treated orally with prednisolone at a dose of $1 \mathrm{mg} \cdot \mathrm{kg}$ body weight ${ }^{-1}$. day $^{-1}$ for 8 weeks (short-term) and thereafter at $0.5 \mathrm{mg} \cdot \mathrm{kg}$ body weight ${ }^{-1} \cdot$ day $^{-1}$ (long-term). These animals are omnivore and thus have more similarities with humans than other animals. By looking at the parallel decline in calcium balance and BMD and the parallel lower bone ash content, the authors concluded that GC-induced osteoporosis was the consequence of reduced intestinal mineral absorption. Scholz-Ahrens et al. [81] think that GCs may directly alter the vitamin $\mathrm{D}$-independent transmucosal absorption of calcium because they did not find large effects on plasma vitamin D metabolites or on PTH. Their conclusion is that alterations in vitamin D metabolites associated with the GC-induced osteoporosis might be the consequence of preexistent disorders.

\section{Regulation by Nutrients}

\section{Dietary $\mathrm{Ca}^{2+}$}

About $70 \%$ of dietary $\mathrm{Ca}^{2+}$ is provided by milk and dairy products, $16 \%$ by green vegetables and fruits, and $6-7 \%$ by drinking water including mineral water [82]. Milk provides large amounts of calcium and phosphorus and other components such as lactose and casein phosphopeptides that may increase calcium absorption and mineral retention. This must be emphasized because intestinal absorption does not completely reflect the bioavailability of calcium. The bioavailability of calcium has been defined as the fraction of dietary $\mathrm{Ca}^{2+}$ that is potentially absorbable by the intestine and can be used for physiological functions, mainly bone mineralization, or to limit bone loss [82]. In brief, the bioavailability of $\mathrm{Ca}^{2+}$ depends on absorbability, urinary excretion and fecal loss of endogenous $\mathrm{Ca}^{2+}$. The effect of several factors affecting the bioavailability of $\mathrm{Ca}^{2+}$ has been extensively examined in several reviews [82-85].

The amount of dietary $\mathrm{Ca}^{2+}$ influences the process of intestinal absorption of the cation. Low $\mathrm{Ca}^{2+}$ diets enhance the efficiency of intestinal $\mathrm{Ca}^{2+}$ absorption [39]. This is an adaptation process performed as a compensation mechanism in order to cover the cation needs of the organism. When dietary $\mathrm{Ca}^{2+}$ is low, serum levels of 
$1,25(\mathrm{OH})_{2} \mathrm{D}_{3}$ are enhanced by stimulation of renal $1 \alpha-$ hydroxylase activity in chicks [9]. Consequently, intestinal $\mathrm{CB}_{28 \mathrm{k}}$ and its mRNA are increased, in addition to the protein expression and activity of $\mathrm{PMCA}_{1 \mathrm{~b}}$ and the $\mathrm{Na}^{+} /$ $\mathrm{Ca}^{2+}$ exchanger $[10,39]$. Low $\mathrm{Ca}^{2+}$ diets also provoke alteration in lipid composition and increment in the fluidity of intestinal BLM [11]. It appears, then, that the $\mathrm{Ca}^{2+}$ exit through BLM from enterocytes of animals adapted to a low $\mathrm{Ca}^{2+}$ diet is greater than that of control animals because of the increment in $\mathrm{PMCA}_{1 b}$ and $\mathrm{Na}^{+} / \mathrm{Ca}^{2+}$ exchanger activities and changes in lipid composition and fluidity of BLM, which might alter the microdomains of cation transporters and, hence, increase their activities [86]. The gene expression of the epithelial $\mathrm{Ca}^{2+}$ channels CaT1 and CaT2 has also been shown to increase by dietary $\mathrm{Ca}^{2+}$ deficiency either in young or adult animals [87]. In other words, the activities of all genes involved in the transcellular pathway $\left(\mathrm{Ca}^{2+}\right.$ channels, $\mathrm{CBs}, \mathrm{PMCA}_{1 \mathrm{~b}}$ and $\mathrm{Na}^{+} / \mathrm{Ca}^{2+}$ exchanger) are enhanced by the low $\mathrm{Ca}^{2+}$ diet, probably by activation of the vitamin $\mathrm{D}$ endocrine system.

\section{Other Nutritional Factors}

In general, carbohydrates increase intestinal $\mathrm{Ca}^{2+} \mathrm{ab}$ sorption, but lactose contained mainly in dairy food seem to be the most efficient one [85]. However, studies done in lactose-tolerant healthy adults did not show an effect of lactose on intestinal $\mathrm{Ca}$ absorption by using a stable strontium test under controlled metabolic conditions [88]. Lately, the use of lactosucrose in humans and animals seems to be very important in order to increase intestinal $\mathrm{Ca}^{2+}$ absorption due to the fact that it promotes a decrease in intestinal $\mathrm{pH}$ increasing the solubility of $\mathrm{Ca}^{2+}$ salts $[89,90]$. Data regarding protein intake and intestinal $\mathrm{Ca}^{2+}$ absorption indicate that dietary protein does not alter the intestinal $\mathrm{Ca}^{2+}$ absorption and, hence, intestinal calcium absorption does not explain hypercalciuria induced by high protein intake [91]. For many years, steatorrhea has been associated with decreased intestinal $\mathrm{Ca}^{2+}$ absorption [92]. However, the data related to the effects of dietary lipids on intestinal $\mathrm{Ca}^{2+}$ absorption are not clear [85]. Human intestinal Caco-2 cells were exposed to conjugated linoleic acid (CLA) and medium chain fatty acids to measure transepithelial and transcellular transport of ${ }^{45} \mathrm{Ca}$, fluorescein transport (a marker of paracellular $\mathrm{Ca}$ transport) and transepithelial electrical resistance (an indicator of permeability). Overall Ca transport and transepithelial electrical resistance in Caco-2 cells were unaffected by exposure to any of the fatty acids for $24 \mathrm{~h}$ or 22 days, whereas paracellular (but not total

Intestinal $\mathrm{Ca}^{2+}$ Absorption transepithelial and transcellular) $\mathrm{Ca}^{2+}$ transport across Caco-2 cells was significantly increased after 22 days [93]. Later, the same authors reported that both isomers of CLA increased overall transepithelial $\mathrm{Ca}^{2+}$ transport as well as transcellular and paracellular $\mathrm{Ca}^{2+}$ transport in monolayers of Caco-2 cells, an effect that could be related to changes in the zona occludens-1 (a tight junction protein) [94]. Recently, Murphy et al. [95] investigated the molecular mechanisms underlying CLA-induced stimulation of $\mathrm{Ca}$ transport using microarray data together with quantitative reverse transcriptase-PCR analysis. They found that zona occludens- 1 , occludin, and claudin- 4 were all upregulated and claudin-1 downregulated by trans-10, cis-12 CLA, which might explain the increase in the paracellular route [95]. However, since they did not find alterations in the genes involved in the transcellular pathway, the mechanism/s involved in this route remain unknown.

The effect of probiotics on stimulation of intestinal $\mathrm{Ca}^{2+}$ absorption has been proposed to be produced by the increased production of short-chain fatty acids by bacteria. In a recent review, it was suggested that prebiotics are the most promising and also the best investigated substances with respect to bone health-promoting potential, as compared to probiotics and synbiotics [96].

Other components of the diet such as phytates, oxalates and tannins can form insoluble complexes with $\mathrm{Ca}^{2+}$, which reduce the cation absorption, this effect being very important when the diets are unbalanced, for example diets lacking dairy products and enriched in fibers [82].

\section{Intestinal $\mathrm{Ca}^{2+}$ Absorption under Different Physiological Conditions}

Intestinal $\mathrm{Ca}^{2+}$ absorption varies according to the age and physiological conditions of individuals. In general, when the needs are high and/or dietary $\mathrm{Ca}^{2+}$ is low, intestinal $\mathrm{Ca}^{2+}$ absorption is found to be more efficient. Growth, gender, pregnancy and lactation and high physical activity increase the $\mathrm{Ca}^{2+}$ demands and, therefore, promote $\mathrm{Ca}^{2+}$ absorption from the intestine. $\mathrm{Ca}^{2+} \mathrm{ab}$ sorption is high during pregnancy. This increment is evident in early to mid pregnancy and precedes the increased $\mathrm{Ca}^{2+}$ demand from the fetus for skeletal growth. This alteration in $\mathrm{Ca}^{2+}$ absorption during pregnancy may be due to an increase in serum calcitriol with little alteration in PTH and calcitonin concentrations [97]. Kent et al. [98], in contrast, demonstrated that the efficiency of 
Table 1. Hormones, factors and physiological conditions affecting intestinal $\mathrm{Ca}^{2+}$ absorption in different species

\begin{tabular}{|c|c|c|}
\hline $\mathrm{Ca}^{2+}$ uptake & $\mathrm{Ca}^{2+}$ transport & $\mathrm{Ca}^{2+}$ exit \\
\hline $\begin{array}{l}\text { Humans } \\
\uparrow \mathrm{D}[45,71] \quad \downarrow \mathrm{A}[22] \\
\uparrow \mathrm{CH}[90,107] \\
\uparrow \operatorname{ITF}[106] \\
\uparrow \mathrm{PB}[121]\end{array}$ & $\begin{array}{l}\uparrow \mathrm{D}[71,122] \\
\uparrow \mathrm{CLA}[95] \\
\uparrow \mathrm{PL}[123]\end{array}$ & \\
\hline $\begin{array}{l}\text { Dog } \\
\uparrow \mathrm{CH}[108] \quad \downarrow 24 \mathrm{D}[109]\end{array}$ & & \\
\hline $\begin{array}{ll}\text { Rat } & \\
\uparrow \mathrm{CT}[63] & \downarrow \text { GC [80] } \\
\uparrow \mathrm{T} 3[67] & \downarrow \mathrm{A}[87] \\
\uparrow \mathrm{PL}[111,112] & \\
\uparrow \mathrm{E}[74] & \\
\uparrow \mathrm{PTH}[59,60] & \\
\uparrow \mathrm{IF}[110] & \\
\uparrow \mathrm{CH}[89] & \\
\uparrow \mathrm{LCa}^{2+}[86] & \end{array}$ & $\begin{array}{l}\uparrow \mathrm{PL}[111,112] \\
\uparrow \mathrm{E}[74] \\
\uparrow \mathrm{LCa}^{2+}[86] \\
\downarrow \mathrm{A}[87] \\
\downarrow \mathrm{GC}[80]\end{array}$ & $\begin{array}{l}\uparrow \mathrm{T} 3[67] \\
\uparrow \mathrm{PL}[111,112]\end{array}$ \\
\hline $\begin{array}{l}\text { Mouse } \\
\uparrow \mathrm{D}[41,113] \downarrow \mathrm{A}[114] \\
\uparrow 24 \mathrm{D}[113] \\
\uparrow \mathrm{E}[75] \\
\uparrow \mathrm{P}[75]\end{array}$ & $\begin{array}{l}\uparrow \alpha \mathrm{D}[113] \\
\downarrow \mathrm{GC}[79]\end{array}$ & \\
\hline $\begin{array}{l}\text { Chick } \\
\uparrow \mathrm{D}[23,31,39] \\
\uparrow \mathrm{LCa}^{2+}[10]\end{array}$ & $\begin{array}{l}\uparrow \mathrm{LCa}^{2+}[11] \\
\uparrow \mathrm{PTH}[116] \\
\downarrow \mathrm{GC}[115]\end{array}$ & $\begin{array}{l}\uparrow \mathrm{D}[31,39] \\
\uparrow \mathrm{LCa}^{2+}[10]\end{array}$ \\
\hline
\end{tabular}

\section{Fish}

$\uparrow$ PTHrP [117]

$\uparrow \mathrm{E}[118]$

$\uparrow \mathrm{D}[119,120]$

$\downarrow 24 \mathrm{D}[119]$

$\mathrm{A}=$ Aging; $\mathrm{CH}=$ carbohydrates; $\mathrm{CLA}=$ conjugated linoleic acid; $\mathrm{CT}=$ calcitonin; $\mathrm{D}=1,25(\mathrm{OH})_{2} \mathrm{D}_{3} ; \alpha \mathrm{D}=1 \alpha-\mathrm{OHD}_{3} ; 24 \mathrm{D}=$ $24,25(\mathrm{OH})_{2} \mathrm{D}_{3} ; \mathrm{E}=$ estrogen; $\mathrm{GC}=$ glucocorticoids; IF = ipriflavone; ITF = inulin-type fructans; $\mathrm{LCa}^{2+}=$ low $\mathrm{Ca}^{2+} ; \mathrm{P}=$ pregnancy; $\mathrm{PB}=$ probiotic bacteria; $\mathrm{PL}=$ prolactin $\mathrm{PTH}=$ parathyroid hormone; $\mathrm{PTHrP}=$ parathyroid hormone-related protein .

intestinal $\mathrm{Ca}^{2+}$ absorption is increased in late pregnancy but not during lactation. Zhu et al. [99] found in rats that at 21 days of gestation both $\mathrm{Ca}^{2+}$ pump and $\mathrm{CB}$ mRNA levels increased 2- to 3 -fold. They also demonstrated that the $\mathrm{Ca}^{2+}$ pump and $\mathrm{CB}$ mRNA remained elevated at 7 days of lactation. Intestinal $\mathrm{Ca}^{2+}$ absorption in pregnant adolescents has also been reported to be significantly higher in the third trimester of pregnancy than in the early postpartum period [100]. In colon biopsies from dairy goats and sheep, it was found that VDR immunohistochemistry revealed a lower staining in early lactation as compared to late lactation, which would mean that VDR seems to be involved in the metabolic changes related to intestinal $\mathrm{Ca}^{2+}$ absorption during the lactation period [101]. Yamagishi et al. [102] found in rats that vitamin $\mathrm{D}$ deficiency during pregnancy produces severe hypocalcemia due to reduced intestinal $\mathrm{Ca}^{2+}$ absorption and elevated fetal demand for the cation.

Braun et al. [103] recently presented data showing that $\mathrm{Ca}^{2+}$ retention in boys is higher than in girls at different $\mathrm{Ca}^{2+}$ intakes, and this difference is attributed to a higher intestinal $\mathrm{Ca}^{2+}$ absorption and lower urinary excretion in boys as compared to girls. To optimize $\mathrm{Ca}^{2+}$ intake it is crucial in adolescents to maximize calcium retention, acquire a good peak of bone mass and prevent osteoporosis later in life. A Spanish study in boys aged 11-14 years on their usual diets revealed that the adolescents absorbed $31 \%$ of dietary intake, retained $20 \%$ of the total intake, but dietary $\mathrm{Ca}^{2+}$ intake failed to meet the recommended values [104]. It has also been demonstrated in adolescents that polymorphisms of the Fok I site in the VDR gene are significantly associated with $\mathrm{Ca}^{2+}$ absorption and $\mathrm{BMD}$; individuals carrying the genotype ff have deficit in whole $\mathrm{Ca}^{2+}$ accretion compared to those with the genotype FF [3].

Advancing age has been associated with lower intestinal $\mathrm{Ca}^{2+}$ absorption [105]. This decrease occurs, at least in part, because of a declination in the serum calcitriol levels, but in addition, a resistance to the actions of calcitriol in the intestine has been reported [22]. Although the mechanisms are poorly known, in women the lack of estrogen during menopause could partially explain this age-associated intestinal resistance to calcitriol. It has also been reported that duodenal TRPV6 expression is not vitamin $\mathrm{D}$-dependent in postmenopausal women [22]. Recent data have shown that in mice, heterozygotes for the VDR gene $\mathrm{KO}$, low levels of VDR produce resistance to intestinal $\mathrm{Ca}^{2+}$ absorption of $1,25(\mathrm{OH})_{2} \mathrm{D}_{3}$. This resistance appears to be generated by the low translation of $\mathrm{CB}_{9 \mathrm{k}}$ that is mediated by binding of VDR to the ligand [2].

Table 1 summarizes the effects of hormones, factors and physiological conditions that participate in the regulation of uptake, transport and extrusion of $\mathrm{Ca}^{2+}$ in the intestine from different species. 


\section{Conclusion}

The intestine is the gate of $\mathrm{Ca}^{2+}$ entry to the entire body. Due to the enormous participation of the cation in different important physiological processes such as muscle contraction, neuronal activity, strength of the skeleton, etc., the mechanisms of intestinal $\mathrm{Ca}^{2+}$ absorption have been studied for many years. The transcellular pathway seems to be highly regulated mainly by calcitriol, which acts through activation of intestinal channels TRPV6 and TRPV5, CBs and PMCA $1 \mathrm{~b}$ and the $\mathrm{Na}^{+} / \mathrm{Ca}^{2+}$ exchanger. PTH, estrogen, GC, thyroid hormone and other hormones also regulate these proteins or their genes by mechanisms under investigation. Dietary $\mathrm{Ca}^{2+}$ and many nutritional factors have been studied in order to elucidate their role in cation absorption. Growth, pregnancy and lactation promote intestinal $\mathrm{Ca}^{2+}$ absorption, while aging and many pathological conditions occur with deterioration in the $\mathrm{Ca}^{2+}$ absorption. Although many findings have been achieved during the last decade on the regulation of intestinal $\mathrm{Ca}^{2+}$ absorption, there are many open questions that need further investigation, for instance: (1) is the $\mathrm{Ca}^{2+}$ pump the main molecule to extrude $\mathrm{Ca}^{2+}$ from the intestinal cell in humans? (2) how is the intestinal $\mathrm{Na}^{+} / \mathrm{Ca}^{2+}$ exchanger regulated by calcitriol and other hormones that stimulate intestinal $\mathrm{Ca}^{2+} \mathrm{ab}-$ sorption? (3) does PTH stimulate intestinal $\mathrm{Ca}^{2+}$ absorption or simply trigger rapid responses in enterocytes that finally do not promote the global process of $\mathrm{Ca}$ absorption? (4) what are the mechanisms by which $\mathrm{Ca}^{2+}$ diffuses between enterocytes? The responses to these and other basic questions on the regulation of intestinal $\mathrm{Ca}$ absorption could give some clues to improve cation absorption in the elderly and in some pathologies, and also to develop nutritional or medical strategies to stimulate the efficiency of intestinal $\mathrm{Ca}^{2+}$ absorption.

\section{References}

$\checkmark 1$ Bronner F: Calcium absorption - a paradigm for mineral absorption. J Nutr 1998;128:917920.

-2 Song Y, Fleet JC: Intestinal resistance to 1,25 dihydroxyvitamin $\mathrm{D}$ in mice heterozygous for the vitamin $\mathrm{D}$ receptor knockout allele. Endocrinology 2007;148:1396-1402.

3 Abrams SA, Griffin IJ, Hawthorne KM, Chen Z, Gunn SK, Wilde M, Darlington G, Shypailo RJ, Ellis KJ: Vitamin D receptor Fok1 polymorphisms affect calcium absorption, kinetics, and bone mineralization rates during puberty. J Bone Miner Res 2005;20: 945-953.

$\checkmark 4$ Wasserman RH: Vitamin D and the dual processes of intestinal calcium absorption. J Nutr 2004; 134:3137-3139.

$\checkmark 5$ Marcus CS, Lengemann FW: Absorption of $\mathrm{Ca}^{45}$ and $\mathrm{Sr}^{85}$ from solid and liquid food at various levels of the alimentary tract of the rat. J Nutr 1962;77:155-160.

6 Cramer CF: Sites of calcium absorption and the calcium concentration of gut contents in the dog. Can J Physiol Pharmacol 1965;43: 75-78.

7 Wasserman RH: Vitamin D and the intestinal absorption of calcium and phosphorus; in Feldman D, Glorieux FH, Pike JW (eds): Vitamin D. San Diego, Academic Press, 1997, pp 259-273.

$>8$ Wali RK, Baum CL, Sitrin MD, Brasitus TA: $1,25(\mathrm{OH})_{2}$ vitamin $\mathrm{D}_{3}$ stimulates membrane phosphoinositide turnover, activates protein kinase $\mathrm{C}$, and increases cytosolic calcium in rat colonic epithelium. J Clin Invest 1990;85: 1296-1303. de Talamoni NT, Mykkanen H, Wasserman RH: Enhancement of sulfhydryl group availability in the intestinal brush border membrane by deficiencies of dietary calcium and phosphorus in chicks. J Nutr 1990;120:11981204.

10 Centeno VA, Diaz de Barboza GE, Marchionatti AM, Alisio AE, Dallorso ME, Nasif R, Tolosa de Talmoni NG: Dietary calcium deficiency increases $\mathrm{Ca}^{2+}$ uptake and $\mathrm{Ca}^{2+}$ extrusion mechanisms in chick enterocytes. Comp Biochem Physiol A Mol Integr Physiol 2004;139:133-141.

11 Tolosa de Talamoni NG: Calcium and phosphorous deficiencies alter the lipid composition and fluidity of intestinal basolateral membranes. Comp Biochem Physiol A Physiol 1996;115:309-315.

12 Hoenderop JG, Nilius B, Bindels RJ: Calcium absorption across epithelia. Physiol Rev 2005;85:373-422.

13 Itoh M, Furuse M, Morita K,Saitou M, Tsukita $S$ : Direct binding of three tight junctionassociated MAGUKs, ZO-1, ZO-2 and ZO-3 with the $\mathrm{COOH}$ termini of claudins. J Cell Biol 1999; 147:1351-1363.

14 Bronner F, Pansu D: Nutritional aspects of calcium absorption. J Nutr 1999;129:9-12.

15 Bronner F: Mechanisms of intestinal calcium absorption. J Cell Biochem 2003;88:387393.

16 Van Abel M, Hoenderop JG, Bindels RJ: The epithelial calcium channels TRPV5 and TRPV6: regulation and implications for disease. Naunyn Schmiedebergs Arch Pharmacol 2005;37:295-306.
17 den Dekker E, Hoenderop JG, Nilius B, Bindels RJ: The epithelial calcium channels, TRPV5 and TRPV6: from identification towards regulation. Cell Calcium 2003;33: 497-507.

18 Hoenderop JG, Voets T, Hoefs S, Weidema F, Prenen J, Nilius B, Bindels RJ: Homo- and heterotetrameric architecture of the epithelial $\mathrm{Ca}^{2+}$ channels TRPV5 and TRPV6. EMBO J 2003;22:776-785.

19 Hoenderop JG, Vennekens R, Muller D, Prenen J, Droogmans G, Bindels RJ, Nilius B: Function and expression of the epithelial $\mathrm{Ca}^{2+}$ channel family: comparison of mammalian ECaC1 and 2. J Physiol 2001;537:747761.

20 Nijenhuis T, Hoenderop JG, Bindels RJ: TRPV5 and TRPV6 in $\mathrm{Ca}^{2+}$ (re)absorption: regulating $\mathrm{Ca}^{2+}$ entry at the gate. Pflügers Arch 2005;451:181-192.

-21 Bianco SD, Peng JB, Takanaga H, Suzuki Y, Crescenzi A, Kos CH, Zhuang L, Freeman MR, Gouveia CH, Wu J, Luo H, Mauro T, Brown EM, Hediger MA: Marked disturbance of calcium homeostasis in mice with targeted disruption of the TRPV6 calcium channel gene. J Bone Miner Res 2007;22: 274-285.

22 Walters JR, Balesaria S, Chavele KM, Taylor V, Berry JL, Khair U, Barley NF, van Heel DA, Field J, Hayat JO, Bhattacharjee A, Jeffery R, Poulsom R: Calcium channel TRPV6 expression in human duodenum: different relationships to the vitamin $\mathrm{D}$ system and aging in men and women. J Bone Miner Res 2006;21:1770-1777. 
23 Tolosa de Talamoni N, Perez A, Alisio A: Effect of cholecalciferol on intestinal epithelial cells. Trends Comp Biochem Physiol 1998;5 179-185.

-24 Venyaminov SY, Klimtchuk ES, Bajzer Z, Craig TA: Changes in structure and stability of calbindin- $\mathrm{D}_{28 \mathrm{~K}}$ upon calcium binding. Anal Biochem 2004;334:97-105.

-25 Lambers TT, Mahieu F, Oancea E, Hoofd L, de Lange F, Mensenkamp AR, Voets T, Nilius B, Clapham DE, Hoenderop JG, Bindels RJ: Calbindin $\mathrm{D}_{28 \mathrm{~K}}$ dynamically controls TRPV5-mediated $\mathrm{Ca}^{2+}$ transport. EMBO J 2006;25:2978-2988.

-26 Airaksinen MS, Eilers J, Garaschuk O Thoenen H, Konnerth A, Meyer M: Ataxia and altered dendritic calcium signaling in mice carrying a targeted null mutation of the calbindin $\mathrm{D}_{28 \mathrm{k}}$ gene. Proc Natl Acad Sci USA 1997;94:1488-1493.

-27 Zheng W, Xie Y, Li G, Kong J, Feng JQ, Li YC: Critical role of calbindin $\mathrm{D}_{28 \mathrm{k}}$ in calcium homeostasis revealed by mice lacking both vitamin $\mathrm{D}$ receptor and calbindin- $\mathrm{D}_{28 \mathrm{k}}$. J Biol Chem 2004;279:52406-52413.

-28 Kutuzova GD, Akhter S, Christakos S, Vanhooke J, Kimmel-Jehan C, Deluca HF: Calbindin $\mathrm{D}_{9 \mathrm{k}}$ knockout mice are indistinguishable from wild-type mice in phenotype and serum calcium level. Proc Natl Acad Sci USA 2006; 103:12377-12381.

-29 Ghijsen WE, De Jong MD, Van Os CH: ATPdependent calcium transport and its correlation with $\mathrm{Ca}^{2+}$-ATPase activity in basolateral plasma membranes of rat duodenum. Biochim Biophys Acta 1982;689:327-336.

-30 Anderson RG: Caveolae: where incoming and outgoing messengers meet. Proc Nat Acad Sci USA 1993;90:10909-10913.

- 31 Alisio A, Cañas F, de Bronia DH, Pereira R, Tolosa de Talamoni N: Effect of vitamin D deficiency on lipid composition and calcium transport in basolateral membrane vesicles from chick intestine. Biochem Mol Biol Int 1997;42:339-347.

32 Ghijsen WE, De Jong MD, Van Os CH: Kinetic properties of $\mathrm{Na}^{+} / \mathrm{Ca}^{2+}$ exchange in basolateral plasma membranes of rat small intestine. Biochim Biophys Acta 1983;730: 85-94.

-33 Philipson KD, Nicoll DA, Matsuoka S, Hryshko LV, Levitsky DO, Weiss JN: Molecular regulation of the $\mathrm{Na}^{+}-\mathrm{Ca}^{2+}$ exchanger. Ann NY Acad Sci 1996;779:20-28.

\34 Lederer WJ, He S, Luo S, duBell W, Kofuji P, Kieval R, Neubauer CF, Ruknudin A, Cheng $\mathrm{H}$, Cannell MB, Rogers TB, Schulze DH: The molecular biology of the $\mathrm{Na}^{+}-\mathrm{Ca}^{2+}$ exchanger and its functional roles in heart, smooth muscle cells, neurons, glia, lymphocytes, and nonexcitable cells. Ann NY Acad Sci 1996;779:7-17.
Dong H, Sellers ZM, Smith A, Chow JY, Bar rett KE: $\mathrm{Na}^{+}-\mathrm{Ca}^{2+}$ exchange regulates $\mathrm{Ca}^{2+}$ dependent duodenal mucosal ion transport and $\mathrm{HCO}_{3}{ }^{-}$secretion in mice. Am J Physiol Gastrointest Liver Physiol 2005;288:G457G465.

36 Hoenderop JG, Hartog A, Stuiver M, Doucet A, Willems PH, Bindels RJ: Localization of the epithelial $\mathrm{Ca}^{2+}$ channel in rabbit kidney and intestine. J Am Soc Nephrol 2000;11: 1171-1178.

37 Blaustein MP, Lederer WJ: Sodium/calcium exchange: its physiological implications. Physiol Rev 1999;79:763-854.

38 Malloy PJ, Pike JW, Feldman D: The vitamin $\mathrm{D}$ receptor and the syndrome of hereditary 1,25-dihydroxyvitamin D-resistant rickets. Endocr Rev 1999;20:156-188.

39 Wasserman RH, Smith CA, Brindak ME, De Talamoni N, Fullmer CS, Penniston JT, Kumar R: Vitamin D and mineral deficiencies increase the plasma membrane calcium pump of chicken intestine. Gastroenterology 1992;102:886-894.

40 Fleet JC, Eksir F, Hance KW, Wood RJ: Vitamin $\mathrm{D}$-inducible calcium transport and gene expression in three Caco-2 cell lines. Am J Physiol Gastrointest Liver Physiol 2002;283: G618-G625.

41 Song Y, Peng X, Porta A, Takanaga H, Peng JB, Hediger MA, Fleet JC, Christakos S: Calcium transporter 1 and epithelial calcium channel messenger ribonucleic acid are differentially regulated by 1,25 dihydroxyvitamin $\mathrm{D}_{3}$ in the intestine and kidney of mice. Endocrinology 2003;144:3885-3894.

42 Akhter S, Kutuzova GD, Christakos S, Deluca HF: Calbindin $D_{9 k}$ is not required for 1,25-dihydroxyvitamin $\mathrm{D}_{3}$-mediated $\mathrm{Ca}^{2+}$ absorption in small intestine. Arch Biochem Biophys 2007;460:227-232.

43 Kato S, Yoshizazawa T, Kitanaka S, Murayama A, Takeyama K: Molecular genetics of vitamin D-dependent hereditary rickets. Horm Res 2002;57:73-78.

44 Meyer MB, Watanuki M, Kim S, Shevde NK, Pike JW: The human transient receptor potential vanilloid type 6 distal promoter contains multiple vitamin $\mathrm{D}$ receptor binding sites that mediate activation by 1,25-dihydroxyvitamin $\mathrm{D}_{3}$ in intestinal cells. Mol Endocrinol 2006;20:1447-1461.

45 Walters JR, Barley NF, Khanji M, RhodesKendler O: Duodenal expression of the epithelial calcium transporter gene TRPV6: is there evidence for vitamin D-dependence in humans? J Steroid Biochem Mol Biol 2004; 89-90:317-319.

46 Norman AW: Minireview: vitamin D receptor: new assignments for an already busy receptor. Endocrinology 2006;147:5542-5548.

47 Chirayath MV, Gajdzik L, Hulla W, Graf J, Cross HS, Peterlik M: Vitamin D increases tight-junction conductance and paracellular $\mathrm{Ca}^{2+}$ transport in Caco-2 cell cultures. Am J Physiol 1998;274:G389-G396.
48 Wasserman R: Vitamin D and intestinal absorption of calcium: a view and overview; in Feldman D, Glorieux FH, Pike JW (eds): Vitamin D, ed 2. San Diego, Academic Press, 2005, pp 411-428.

49 McCormick CC: Passive diffusion does not play a major role in the absorption of dietary calcium in normal adults. J Nutr 2002;132: 3428-3430.

50 Bronner F, Slepchenko B, Wood RJ, Pansu D: The role of passive transport in calcium absorption. J Nutr 2003;133:1426.

51 Balsan S, Garabédian M, Larchet M, Gorski AM, Cournot G, Tau C, Bourdeau A, Silve C, Ricour C: Long-term nocturnal calcium infusions can cure rickets and promote normal mineralization in hereditary resistance to 1,25-dihydroxyvitamin D. J Clin Invest 1986;77:1661-1667.

52 Bliziotes M, Yergey AL, Nanes MS, Muenzer J, Begley MG, Vieira NE, Kher KK, Brandi ML, Marx SJ: Absent intestinal response to calciferols in hereditary resistance to 1,25 dihydroxyvitamin D: documentation and effective therapy with high dose intravenous calcium infusions. J Clin Endocrinol Metab 1988;66:294-300.

53 Bronner F, Salle BL, Putet G, Rigo J, Senterre $\mathrm{J}$ : Net calcium absorption in premature infants: results of 103 metabolic balance studies. Am J Clin Nutr 1992;56:1037-1044. Erratum in: Am J Clin Nutr 1993;57:451.

54 Pansu D, Bellaton C, Bronner F: Developmental changes in the mechanisms of duodenal calcium transport in the rat. Am J Physiol 1983;244:G20-G26.

55 Ireland P, Fordtran JS: Effect of dietary calcium and age on jejunal calcium absorption in humans studied by intestinal perfusion. J Clin Invest 1973;52:2672-2681.

56 Sheikh MS, Ramirez A, Emmett M, Santa Ana C, Schiller LR, Fordtran JS: Role of vitamin D-dependent and vitamin D-independent mechanisms in absorption of food calcium. J Clin Invest 1988;81:126-132.

57 Krawitt EL, Schedl HP: In vivo calcium transport by rat small intestine. Am J Physiol 1968;214:232-236.

58 Favus MJ: Factors that influence absorption and secretion of calcium in the small intestine and colon. Am J Physiol 1985;248:G147G157.

59 Picotto G, Massheimer V, Boland R: Parathyroid hormone stimulates calcium influx and the CAMP messenger system in rat enterocytes. Am J Physiol 1997;273:C1349C1353.

60 Picotto G: Rapid effects of calciotropic hormones on female rats enterocytes: combined actions of 1,25-vitamin D3, PTH and $17 \beta$ estradiol on intracellular calcium regulation. Horm Metab Res 2001;33:733-738.

61 Gentili C, Morelli S, de Boland AR: Characterization of $\mathrm{PTH} / \mathrm{PTH} \mathrm{PP}$ receptor in rat duodenum: effects of ageing. J Cell Biochem 2003;88:1157-1167. 
-62 Nemere I, Larsson D: Does PTH have a direct effect on intestine? J Cell Biochem 2002;86: 29-34.

-63 Jaeger P, Jones W, Clemens TL, Hayslett JP. Evidence that calcitonin stimulates 1,25-dihydroxyvitamin $\mathrm{D}$ production and intestinal absorption of calcium in vivo. J Clin Invest 1986;78:456-461.

64 Yoshida N, Yoshida T, Nakamura A, Monkawa T, Hayashi M, Saruta T: Calcitonin induces 25-hydroxyvitamin $\mathrm{D}_{3}$ 1alpha-hydroxylase mRNA expression via protein kinase $\mathrm{C}$ pathway in LLC-PK1 cells. J Am Soc Nephrol 1999; 10:2474-2479.

65 Hirsch PF, Baruch H: Is calcitonin an important physiological substance? Endocrine 2003;21:201-208

-66 Farnsworth AE, Dobyns BM: Hypercalcaemia and thyrotoxicosis. Med J Aust 1974;2: 782-784.

67 Kumar V, Prasad R: Thyroid hormones stimulate calcium transport systems in rat intestine. Biochim Biophys Acta 2003;1639:185194.

68 Cross HS, Peterlik M: Calcium and inorganic phosphate transport in embryonic chick intestine: triiodothyronine enhances the genomic action of 1,25-dihydroxycholecalciferol. J Nutr 1988;118:1529-1534.

-69 Cross HS, Debiec H, Peterlik M: Thyroid hormone enhances the genomic action of calcitriol in the small intestine. Prog Clin Biol Res 1990;332:163-180.

70 Bouillon R, Carmeliet G, Van Cromphaut S: Intestinal calcium absorption: lessons from knockout mice and men; in Feldman D, Glorieux FH, Pike JW (eds): Vitamin D, ed 2. San Diego, Academic Press, 2005, pp 429-452.

71 Cotter AA, Cashman KD: Effect of 17betaoestradiol on transepithelial calcium transport in human intestinal-like Caco-2 cells and its interactions with 1,25-dihydroxycholecalciferol and 9-cis retinoic acid. Eur J Nutr 2006;45:234-241.

-72 Colin EM, van den Bemd GJ, van Aken M, Christakos S, de Jonge HR, DeLuca HF, Prahl JM, Birkenhäger JC, Buurman CJ, Pols HA, van Leeuwen JP: Evidence for involvement of 17beta-estradiol in intestinal calcium absorption independent of 1,25-dihydroxyvitamin $\mathrm{D}_{3}$ level in the rat. J Bone Miner Res 1999; 14:57-64.

73 Campbell-Thompson M, Lynch IJ, Bhardwaj B: Expression of estrogen receptor (ER) subtypes and ERbeta isoforms in colon cancer. Cancer Res 2001;61:632-640.

-74 Van Abel M, Hoenderop JG, Van der Kemp AW, Van Leeuwen JP, Bindels RJ: Regulation of the epithelial $\mathrm{Ca}^{2+}$ channels in small intestine as studied by quantitative mRNA detection. Am J Physiol Gastrointest Liver Physiol 2003;285:G78-G85.
75 Van Cromphaut SJ, Rummens K, Stockmans I, Van Herck E, Dijcks FA, Ederveen AG, Carmeliet P, Verhaeghe J, Bouillon R, Carmeliet G: Intestinal calcium transporter genes are upregulated by estrogens and the reproductive cycle through vitamin $\mathrm{D}$ receptor-independent mechanisms. J Bone Miner Res 2003;18:1725-1736.

76 Cotter AA, Cashman KD: The effect of two dietary and a synthetic phytoestrogen on transepithelial calcium transport in human intestinal-like Caco-2 cells. Eur J Nutr 2005; 44:72-78.

77 Reid IR: Glucocorticoid osteoporosis mechanisms and management. Eur J Endocrinol 1997;137:209-217.

78 Van Cromphaut SJ, Stockmans I, Torrekens S, Herck EV, Carmeliet G, Bouillon R: Duodenal calcium absorption in dexamethasone-treated mice: functional and molecular aspects. Arch Biochem Biophys 2007;460: 300-305.

79 Lee GS, Choi KC, Jeung EB: Glucocorticoids differentially regulate expression of duodenal and renal calbindin- $\mathrm{D}_{9 \mathrm{k}}$ through glucocorticoid receptor-mediated pathway in mouse model. Am J Physiol Endocrinol Metab 2006;290:E299-E307.

-80 Huybers S, Naber TH, Bindels RJ, Hoenderop JG: Prednisolone-induced $\mathrm{Ca}^{2+}$ malabsorption is caused by diminished expression of the epithelial $\mathrm{Ca}^{2+}$ channel TRPV6. Am J Physiol Gastrointest Liver Physiol 2007; 292:G92-G97.

81 Scholz-Ahrens KE, Delling G, Stampa B, Helfenstein A, Hahne HJ, Açil Y, Timm W, Barkmann R, Hassenpflug J, Schrezenmeir J, Glüer CC: Glucocorticosteroid-induced osteoporosis in adult primiparous Göttingen miniature pigs: effects on bone mineral and mineral metabolism. Am J Physiol Endocrinol Metab 2007;293:E385-E395.

82 Guéguen L, Pointillart A: The bioavailability of dietary calcium. J Am Coll Nutr 2000; 19(suppl):119S-136S.

83 Allen LH: Calcium bioavailability and absorption: a review. Am J Clin Nutr 1982;35: $783-808$.

84 Pointillart A, Guéguen L: Influence des fibres alimentaires sur la biodisponibilité des minéraux. Cah Ensbana 1992;8:157-182.

85 Buzinaro EF, Almeida RN, Mazeto GM: Bioavailability of dietary calcium. Arq Bras Endocrinol Metabol 2006;50:852-861.

86 Tolosa de Talamoni N, Centeno V: Low calcium diets in humans and in experimental animals: classic models to understand calcium homeostasis and vitamin D endocrine system. Endocrinología 1999;46:241-244.

87 Brown AJ, Krits I, Armbrecht HJ: Effect of age, vitamin $\mathrm{D}$, and calcium on the regulation of rat intestinal epithelial calcium channels. Arch Biochem Biophys 2005;437:5158.
8 Zittermann A, Bock P, Drummer C, Scheld K, Heer M, Stehle P: Lactose does not enhance calcium bioavailability in lactose-tolerant, healthy adults. Am J Clin Nutr 2000; 71:931-936.

89 Kishino E, Norii M, Fujita K, Hara K, Teramoto F, Fukunaga M: Enhancement by lactosucrose of the calcium absorption from the intestine in growing rats. Biosci Biotechnol Biochem 2006;70:1485-1488.

90 Teramoto F, Rokutan K, Sugano Y, Oku K, Kishino E, Fujita K, Hara K, Kishi K, Fukunaga $\mathrm{M}$, Morita $\mathrm{T}$ : Long-term administration of 4G-beta-D-galactosylsucrose (lactosucrose) enhances intestinal calcium absorption in young women: a randomized, placebo-controlled 96-wk study. J Nutr Sci Vitaminol 2006;52:337-346.

91 Kerstetter JE, O’Brien KO, Insogna KL: Dietary protein, calcium metabolism, and skeletal homeostasis revisited. Am J Clin Nutr 2003;78:S584-S592.

92 Haderslev KV, Jeppesen PB, Mortensen PB, Staun M: Absorption of calcium and magnesium in patients with intestinal resections treated with medium chain fatty acids. Gut 2000;46:819-823.

93 Jewell C, Cashman KD: The effect of conjugated linoleic acid and medium-chain fatty acids on transepithelial calcium transport in human intestinal-like Caco-2 cells.Br J Nutr 2003;89:639-647.

94 Jewell C, Cusack S, Cashman KD: The effect of conjugated linoleic acid on transepithelial calcium transport and mediators of paracellular permeability in human intestinal-like caco-2 cells. Prostaglandins Leukot Essent Fatty Acids 2005;72:29-39.

95 Murphy EF, Jewell C, Hooiveld GJ, Muller M, Cashman KD: Conjugated linoleic acid enhances transepithelial calcium transport in human intestinal-like Caco-2 cells: an insight into molecular changes. Prostaglandins Leukot Essent Fatty Acids 2006;74:295301.

96 Scholz-Ahrens KE, Ade P, Marten B, Weber P, Timm W, Açil Y, Glüer CC, Schrezenmeir J: Prebiotics, probiotics, and synbiotics affect mineral absorption, bone mineral content, and bone structure. J Nutr 2007;137:S838S846.

97 Prentice A: Maternal calcium metabolism and bone mineral status. Am J Clin Nutr 2000;71:S1312-S1316.

98 Kent GN, Price RI, Gutteridge DH, Rosman KJ, Smith M, Allen JR, Hickling CJ, Blakeman SL: The efficiency of intestinal calcium absorption is increased in late pregnancy but not in established lactation. Calcif Tissue Int 1991;48:293-295. 
$\$ 99$ Zhu Y, Goff JP, Reinhardt TA, Horst RL: Pregnancy and lactation increase vitamin D-dependent intestinal membrane calcium adenosine triphosphatase and calcium binding protein messenger ribonucleic acid expression. Endocrinology 1998;139:3520 3524.

100 O’Brien KO, Nathanson MS, Mancini J, Witter FR: Calcium absorption is significantly higher in adolescents during pregnancy than in the early postpartum period. Am J Clin Nutr 2003;78:1188-1193.

101 Liesegang A, Riner K, Boos A: Effects of gestation and lactation on vitamin $\mathrm{D}$ receptor amounts in goats and sheep. Domest Anim Endocrinol 2007;33:190-202.

102 Yamagishi N, Sassa H, Sato R, Taniguchi K, Okura N, Sato S, Naito Y: Calcium metabolism in pregnant rats fed a vitamin D-depleted diet. J Vet Med Sci 2007;69:441443.

103 Braun M, Martin BR, Kern M, McCabe GP, Peacock M, Jiang Z, Weaver CM: Calcium retention in adolescent boys on a range of controlled calcium intakes. Am J Clin Nutr 2006;84:414-418.

104 Seiquer I, Lopez-Frias M, Munoz-Hoyos A, Galdo G, Delgado-Andrade C, Mesias M, Navarro MP: Dietary calcium utilization among a group of Spanish boys aged 11-14 years on their usual diets. J Physiol Biochem 2006;62:9-16.

105 Nordin BE, Need AG, Morris HA, O’Loughlin PD, Horowitz M: Effect of age on calcium absorption in postmenopausal women. Am J Clin Nutr 2004;80:9981002.

106 Raschka L, Daniel H: Mechanisms underlying the effects of inulin-type fructans on calcium absorption in the large intestine of rats. Bone 2005;37:728-735.

107 Abrams SA, Hawthorne KM, Aliu O, Hicks PD, Chen Z, Griffin IJ: An inulin-type fructan enhances calcium absorption primarily via an effect on colonic absorption in humans. J Nutr 2007;137:2208-2212.
108 Beynen AC, Kappert HJ, Yu S: Dietary lactulose decreases apparent nitrogen absorption and increases apparent calcium and magnesium absorption in healthy dogs. J Anim Physiol Anim Nutr 2001;85:67-72.

109 Tryfonidou MA, Stevenhagen JJ, van den Bemd GJ, Oosterlaken-Dijksterhuis MA, DeLuca HF, Mol JA, van den Brom WE, van Leeuwen JP, Hazewinkel HA: Moderate cholecalciferol supplementation depresses intestinal calcium absorption in growing dogs. J Nutr 2002;132:2644-2650.

110 Arjmandi BH, Khalil DA, Hollis BW: Ipriflavone, a synthetic phytoestrogen, enhances intestinal calcium transport in vitro. Calcif Tissue Int 2000;67:225-229.

111 Charoenphandhu N, Limlomwongse L, Krishnamra N: Prolactin directly stimulates transcellular active calcium transport in the duodenum of female rats. Can J Physiol Pharmacol 2001;79:430-438.

112 Charoenphandhu N, Krishnamra N: Prolactin is an important regulator of intestinal calcium transport. Can J Physiol Pharmacol 2007;85:569-581.

113 Hoenderop JG, van der Kemp AW, Urben CM, Strugnell SA, Bindels RJ: Effects of vitamin $\mathrm{D}$ compounds on renal and intestinal $\mathrm{Ca}^{2+}$ transport proteins in 25 hydroxyvitamin D3-1alpha-hydroxylase knockout mice. Kidney Int 2004;66:10821089.

114 van Abel M, Huybers S, Hoenderop JG, van der Kemp AW, van Leeuwen JP, Bindels RJ: Age-dependent alterations in $\mathrm{Ca}^{2+}$ homeostasis: role of TRPV5 and TRPV6. Am J Physiol Renal Physiol 2006;291:F1177F1183.

115 Feher JJ, Wasserman RH: Intestinal calcium-binding protein and calcium absorption in cortisol-treated chicks: effects of vitamin D3 and 1,25-dihydroxyvitamin D3. Endocrinology 1979;104:547-551.
16 Nemere I, Norman AW: Parathyroid hormone stimulates calcium transport in perfused duodena from normal chicks: comparison with the rapid (transcaltachic) effect of 1,25-dihydroxyvitamin D3. Endocrinology 1986;119:1406-1408.

117 Fuentes J, Figueiredo J, Power DM, Canário AV: Parathyroid hormone-related protein regulates intestinal calcium transport in sea bream (Sparus auratus). Am J Physiol Regul Integr Comp Physiol 2006;291: R1499-R1506.

118 Guerreiro PM, Fuentes J, Canario AV, Power DM: Calcium balance in sea bream (Sparus aurata): the effect of oestradiol-17beta. J Endocrinol 2002;173:377-385.

119 Sundell K, Björnsson BT: Effects of vitamin D3, 25(OH) vitamin D3, 24, 25(OH)2 vitamin $\mathrm{D} 3$, and $1,25(\mathrm{OH}) 2$ vitamin $\mathrm{D} 3$ on the in vitro intestinal calcium absorption in the marine teleost, Atlantic cod (Gadus morhua). Gen Comp Endocrinol 1990;78: 74-79.

120 Fenwick JC, Smith K, Smith J, Flik G: Effect of various vitamin $\mathrm{D}$ analogs on plasma calcium and phosphorus and intestinal calcium absorption in fed and unfed American eels, Anguilla rostrata. Gen Comp Endocrinol 1984;55:398-404.

121 Gilman J, Cashman KD: The effect of probiotic bacteria on transepithelial calcium transport and calcium uptake in human intestinal-like Caco-2 cells. Curr Issues Intest Microbiol 2006;7:1-5.

122 Nakane M, Ma J, Rose AE, Osinski MA, Wu-Wong JR: Differential effects of vitamin $\mathrm{D}$ analogs on calcium transport. J Steroid Biochem Mol Biol 2007;103:84-89.

123 Jantarajit W, Thongon N, Pandaranandaka J, Teerapornpuntakit J, Krishnamra N, Charoenphandhu N: Prolactin-stimulated transepithelial calcium transport in duodenum and Caco-2 monolayer are mediated by the phosphoinositide 3-kinase pathway. Am J Physiol Endocrinol Metab 2007;293: E372-E384. 